Удк 101:37

М. І. Захаріна, ст. викладач,

А. Д. Мекшун, ст. викладач

\title{
ФІЛОСОФСЬКО-ПЕДАГОГІЧНЕ ОСМИСЛЕННЯ В. ЗЕНЬКОВСЬКИМ ЯКОСТІ ОСВІТИ: ПАРАЛЕЛІ ІЗ СУЧАСНІСТЮ
}

Актуальність теми дослідження. 3 точки зору соціальної фрілософрії, яка широко використовує антропометричний підхід, ключове призначення освіти, а відтак - $і$ джерела оцінювання їі якості, полягає у позитивних змінах, що відбуваються на рівні індивіда (людини).

Постановка проблеми. В той же час людина як об'єкт впливу результатів освіти (освітнього процесу) не завжди здатна (вірніше - частіше нездатна) неупереджено оцінити якість отриманої освіти.

Аналіз останніх досліджень і публікацій. Проблему якості освіти досліджували такі вчені як В. Андрущенко, В. Бех, В. Кремень, Б. Майбєр, В. Наливайко, С. Терпищий, О. Чабала тощо.

Виділення недосліджених частин загальної проблем. Стаття присвячена аналізу педагогічних та фрілософрських поглядів В. В. Зеньковського, який був представником мислителів релігійного відродження, зусиллями яких була створена фрілософрія початку і першої половини XX століття.

Постановка завдання. Реконструкція поглядів В. В. Зеньковського має істотне значення для розуміння сутності і особливостей якості освіти та особливого значення для сучасності.

Викладення основного матеріалу. В. В. Зеньковський сформулював ключову ознаку якісної освіти - по-перше, забезпечувати гармонійний розвиток особистості (зокрема, через вивчення «загальних» предметів), а по-друге, забезпечувати суспільне благо у вигляді фрахівців належної якості (зокрема, через отримання індивідами знань та навичок відповідно до обраної спеціальності). В цій тезі простежується призначення освітнього процесу як своєрідної «соціальної відповіді» на індивідуальні та суспільні запити. Здідно з В. Зеньковським, така «соціальна відповідь» має простежуватися на всіх рівнях освіти - і у середній освіті, і у вищій освіти.

Висновки відповідно до статmі. Якість освіти В. В. Зеньковський розглядав широко, ставлячи на порядок денний і питання задоволення освітніх потреб особистості, i їі підготовку до соціальної взаємодії, і необхідність задоволення запитів держави і суспільства.

Ключові слова: Зеньковський; духовність; свобода; національне виховання; національна школа; якість освіти.

M. I. Zakharina, Senior Lecturer, A. D. Mekhun, Senior Lecturer

\section{PHILOSOPHICAL AND PEDAGOGICAL COMPREHENSION OF EDUCATION QUALITY BY V. ZENKOVSKY : PARALLELS WITH THE PRESENT}

Urgency of the research. From the point of view of social philosophy, which is widely uses the anthropometric approach, the key purpose of education, and therefore - the sources of evaluation of its quality, is the positive changes occurring at the level of the individual (human).

Target setting. Even educators (consumers, students, pupils, audience) who have fully utilized the service can not objectively evaluate the quality of education that results from a particular educational process.

Actual scientific researches and issues analysi. The problem of the quality of education was studied by such scholars as B. Andrushenko, V. Beh, V. Kremen, B. Miber, V. Nalivayko, S. Terpishch, $O$. Chabala and others.

Uninvestigated parts of general matters defini. The article is devoted to the analysis of pedagogical and philosophical views of V. V. Zenkovsky, who was a representative of the thinkers of the religious revival, whose efforts were created by the philosophy of the beginning and the first half of the $X X$ century. 
The research objective. Reconstruction of $V$. $V$. Zenkovsky's views is essential for understanding the essence and peculiarities of the quality of education and of particular significance for the present.

The statement of basic material. $V$. V. Zenkovsky formulated a key feature of qualitative education - first, to ensure the harmonious development of the individual (in particular, through the study of "general" subjects), and secondly, to provide public good in the form of specialists of appropriate quality (in particular.

Conclusions. The quality of education V. V. Zenkovsky considered widely, placing on the agenda and the issue of meeting the educational needs of the individual, and its preparation for social interaction, and the need to meet the demands of the state and society.

Keywords: Zenkovsky; spirituality; freedom; national education; national school; quality of education.

\section{DOI: 10.25140/2412-1185-2018-2(12)-36-43}

Актуальність теми дослідження. Освітній процес, як і будь-який інший процес у соціальній сфері, має бути спрямований на отримання певного результату. Вказаний результат у суспільній свідомості має сприйматися як загальносуспільне благо (або набір благ), заради якого освітній процес здійснюється. До загального блага мають доступ усі члени суспільства, і вважається, що таке благо підтримує життєздатність самого суспільства, забезпечує його розвиток і прогрес. Ті результати, які завчасно планувалися (очікувалися), можуть бути виражені через поняття якості (в розумінні: якість - це ті результати, які очікувалися і які приносять якнайбільшу користь). Якість освіти, таким чином, може бути висвітлена через суспільний прояв освіти, що реалізується за допомогою освітнього процесу.

В той же час якість освіти - поняття дуже неоднорідне. В науковій літературі немає єдиної точки зору з питання «якість освіти», що і не дивно, оскільки різні дослідники по-різному сприймають ключовий результат освіти і освітнього процесу.

Якість як фрілософська категорія позначає притаманну речам специфічну визначеність, яка тотожна з їхнім буттям і відрізняє їх від інших речей. Якість також розуміють як здатність речей або певних процесів задовольняти певні потреби (суспільства, держави, людей, окремої людини). На практичному рівні якість сприймають як ступінь відповідності певного результату задекларованим планам (або стандартам).

Постановка проблеми. Поняття якості відносно освіти та освітнього процесу не слід вважати новим або таким, що зустрічається лише у наукових розвідках сучасних авторів. Поняття якості при оцінювання результативності освіти використовував ще Аристотель.

Огляд основних відповідних наукових джерел дає змогу зробити висновок, що ключовим результатом освітнього процесу різні дослідники вважають:

- правильне викладення освітнього матеріалу на основі затверджених методик,

- набуття особою (учнем, студентом, слухачем) абстрактних або конкретних навичок до наукової або практичної діяльності,

- набуті здобувачем освіти (учнем, студентом) знання,

- набуті здобувачем освіти компетентності,

- надання освітньої послуги відповідно до вимог закону, стандартів, правил, договору тощо,

- загальна задоволеність учасників освітнього процесу.

- сумлінне виконання навчальних завдань.

Навіть поверховий аналіз запропонованих результатів освітнього процесу дає змогу зробити висновок про їхню множинність, причому наведені результативні критерії не можуть дати відповідь на запитання про ступінь реалізації суспільного призначення освіти. Результативність освіти в таких умовах доцільно і слід оцінювати в системі параметрів конкретного дослідження, виходячи з його предмета.

Ще складніше сформувати теоретико-методологічні настанови відносно якості освіти, оскільки якість не може бути відокремлена від результату. Якщо взяти до уваги, що за загальним визначенням якість - це ступінь реалізації потреб (або ступінь задоволеності внаслідок реалізації потреб), то можна зробити припущення, що якість освіти можна визначити через це ступінь реалізації 
освітніх потреб людини або суспільства. Одначе вказаний ступінь можна оцінити шляхом співвідношення між очікуваним (бажане) та фрактичним (реальне), тобто між мрією і результатом.

Якість освіти, таким чином - це категорія, яку можна «виміряти», але шкала цього виміру залежить від того, що вважати «очікуваним результатом» (або благом) освітнього процесу.

Аналіз останніх досліджень і публікацій. Б. Майбєр та Н. Наливайко справедливо наголошують на тому, що однією з центральних категорій в межах концептуального аналізу системи освіти є якість освіти, що пов'язано із вимогами щодо не стільки кількісних, скільки якісних змін системи освіти та її функцій [8, с. 4]. О. Чабала вірно зазначає, що категорію якості на підставі аналізу різних досліджень можна виокремити за такими аспектами: онтологічним - категорія, яка хоч і передбачає виокремлення змістовних характеристик, але досить часто зробити це практично неможливо; екзистенціальним - будь-яка якість має певну кількість сутностей, які піддаються вимірюванню та спогляданню; ноуменологічним - явища та предмети можна осягнути, визначити їх сутність лише за умови наявності розуму; метафізичним - категорія є всезагальною для соціальних суб'єктів тощо [ 10, с. 23].

При цьому якість освіти і окремі вчені, і більшість практиків досить часто ототожнюють 3 якістю навчання або якістю знань. На нашу думку, якість освіти - поняття значно ширше, оскільки функціональним призначенням освіти є не лише навчання або «передача знань» .

С. Терпищий справедливо наголошує, що якість освіти тісно пов'язана з проблемою її стандартизації, вбачаючи у стандартах джерело ознак якості як гарантії отриманого бажаного результату (9, с. 31). Дослідник вірно зазначає, що стандартизація зовсім не означає одноманітність. Навпаки, освітні стандарти мають створити передумови для заохочення у учнів (студентів) креативності, творчості, адаптивності до соціуму тощо.

Виділення недосліджених частин загальної проблеми. В. В. Зеньковський - вітчизняний фрілософ, педагог та психолог, який ще XX ст.. розмірковував на тему якості освіти та навчання. Його погляди залишаються актуальними і на даний час, в умовах модернізації якості української освіти.

Постановка завдання. Метою нашої статті $€$ розгляд деяких положень про якість та значення освіти в творчості вітчизняного вченого В. В. Зеньковського та значення його поглядів у сучасному освітньому дискурсі.

Виклад основного матеріалу. В процесі осмислення якості освіти як категорії, яка має давати відповіді на питання облаштування навчально-виховного процесу на практичному рівні, було сформульоване наступне бачення: «Якість освіти - це: багатовимірна модель соціальних норм і вимог до особистості, освітнього простору, у якому відбувається її розвиток, та системи освіти, яка реалізує модель на певних етапах навчання; інтегральна характеристика реальних досягнутих результатів освітніх процесів і навчальних програм; міра відповідності нормативним вимогам, соціальним та особистісним очікуванням». В Законі України «Про вищу освіту» поняття «якість вищої освіти» та «якість освітньої діяльності» розмежовано. Отже, на думку законодавця, яка сорормульована на основі опрацювання пропозицій вчених та практиків, якість освіти та якість освітньої діяльності - поняття не тотожні, різні. У зазначеному Законі вказано, що якість вищої освіти - рівень здобутих особою знань, умінь, навичок, інших компетентностей, що відображає її компетентність відповідно до стандартів вищої освіти, в той же час якість освітньої діяльності визначається як рівень організації освітнього процесу у вищому навчальному закладі, що відповідає стандартам вищої освіти, забезпечує здобуття особами якісної вищої освіти та сприяє створенню нових знань [1].

При визначенні суспільного призначення освіти (а відтак - і якості освіти) пропонуємо керуватися положеннями законодавчих актів з питань освіти. Річ у тому, що положення законодавчих актів з питань освіти представляють собою так званий «суспільний консенсус», в якому у найбільш виразній формі наведено зміст суспільного запиту до освіти (освітнього процесу). Законодавчий акт в цьому розумінні представляє собою вираз волі народу (соціуму), у тому числі в частині суспільних очікувань до результатів освіти. У преамбулі Закону України «Про освіту» законодавець вказує: «Метою освіти є всебічний розвиток людини як особистості та найвищої цінності суспільства, розвиток ії талантів, розумових і фізичних здібностей, виховання високих моральних якостей, формування громадян, здатних до свідомого суспільного вибору, збагачення на цій основі інтелектуального, творчого, культурного потенціалу народу, підвищення освітнього рівня народу, забезпечення народного господарства кваліфікованими фахівцями». 
Запропоноване розуміння мети освіти дозволяє зробити певні узагальнення щодо суспільного призначення освіти, а відтак - і до результату освітнього процесу. В той же час неважко помітити, що запропоноване законодавцем визначення немов би охоплює різний рівень користувачів (людина, особистість, суспільство, держава, народ).

Основне вміння, яке має бути надане студенту (слухачу) під час споживання ним освітньої послуги у закладі вищої або професійної освіти - це вміння до самостійної роботи, в першу чергу вміння до самостійного пошуку, опрацювання та узагальнення інформації, її інтерпретації та перетворення на необхідне для роботодавця знання, що може використовуватися у певному виді діяльності. Сучасні освітні заклади мають прививати навички до самонавчання, саморозвитку, ведення власної справи, комунікативного спілкування.

Про призначення освіти (зокрема, шкільної) як наукової проблеми у найбільш загальному її розумінні писав і В. В. Зеньковський. «Школа має підготувати дитину до життя, має сприяти розкриттю та розвитку її особистості, її сил, аби перед початком періоду самостійного життя вона володіла усім тим у «традиції» (включаючи сюди і знання), усім тим в самій себе, що буде потрібно їй у житті, - писав мислитель. - Формулюючи так завдання школи, ми визначаємо їх до відомого ступеня формально, оскільки не торкаємося змісту того, що потрібно при підготовці до життя - але зараз для нас важливо встановити ту загальну та, звісно, безсумнівну задачу школи [6].

Таким чином, можна зробити висновок, що ключове завдання формальної освіти як соціального феномена полягало у тому, або підготувати учня (студента) до майбутньої самостійної діяльності, до самостійного «життя». Отже, якісна освіта має завжди відповідати цьому критерію тобто, готувати індивіда до самостійних дій, до адаптації у соціумі (соціальних колективах).

В цьому, на думку В. Зеньковського, полягає ключова (провідна) цінність освіти та діяльності формальних освітніх інститутів.

Якість освіти може вимірюватися і в соціальному аспекті. Освітній процес завжди має соціальну складову, адже в результаті цього процесу задовольняються не лише індивідуальні потреби людини, але і колективні потреби (приміром, підготовка фрахівців високої кваліфікації для подальшого соціально-економічного розвитку). В той же час передача знань має і емоційну складову, що нерідко формується під впливом іміджу освіти як такої, а також очікувань індивіда щодо набутих компетентностей.

Освітній процес - це продукт спільної взаємодії кількох елементів: держави, навчального закладу, слухача (учня, студента), інколи - ще і майбутнього роботодавця (який може впливати на зміст навчальної програми, у тому числі шляхом організації виробничої практики). Всі ці суб’єкти можуть формувати вимоги до якості освіти. Причому об'єктивна та суб'єктивна цінності освітньої послуги не збігаються. Об'єктивні дані, що характеризують динаміку якості освітньої послуги, нерідко не усвідомлюються суб'єктами освітнього процесу (учасниками взаємодії), в тому числі надавачем і споживачем. Наведені нами узагальнення дозволяють припустити, що якість освіти, оскільки вона залежить від багатьох чинників та суб'єкту оцінки, взагалі не може бути виміряна традиційними засобами. Приміром, В. В. Зеньковський задавав собі та читачам на перший погляд просте запитання: «Що робить школу або взагалі будь-яке соціальне середовище педагогічним?» [6] Мислитель звертав увагу на те, що школа є видом соціальної структури. «При цьому поняття соціальної структури включає три види, - писав В. В. Зеньковський. - Перший - це структура ієрархічна, тобто хтось стоїть вище, хтось нижче. Другий вид - це кооперація, тобто співробітництво рівний, і лише для технічної зручності хтось отримує більше значення, аніж інші. Третій вид... - це протипоставлення одних іншим, відкрите та постійне суперництво, тобто боротьба» [6, с. 59].

В. Зеньковський, розвиваючи цю тезу, наводить перелік заборон (обмежень), які застосовуються у школі (освітній установі) по відношенню до учня. Перелік цих заборон традиційно широкий читання книжок, грубість, запізнення, непристойні висловлювання тощо. Але, робить висновок вчений, джерелом цих обмежень, по суті, $є$ саме соціальна структура школи як особливого соціального інституту. Обмеження, таким чином, виступають певним мірилом якості. Якщо певна соціальна система функціонує в завданих параметрах (у першу чергу в параметрах обмежувальних) це означатиме, що ця система працює «правильно», або, якщо говорити сучасною мовою - якісно.

Якість освіти, таким чином, виступає не простою теоретико-філософською парадигмою, а науково-практичним інструментом оцінювання відповідності школи певним соціальним установкам (зокрема, щодо соціальної структури та її проявам). Таких установок, звісно, досить багато, але 
вони необхідні, оскільки слугують певною «гарантією» отримання очікуваного результату від навчання (іншими словами - «гарантією» належної якості освіти).

Якість освіти, таким чином, слід сприймати не просто як результат функціонування чогось або когось, а скоріше - «продукт» діяльності школи, тобто певного соціального інституту (у вузькому значенні - соціальної структури). Причому не простий «продукт», а такий, що впливає на інші сторони соціальної діяльності. Школа, оскільки вона є специфічним соціальним інститутом, здатна забезпечувати належну (бажану, ідеальну) якість освіти - як результат чогось бажаного для суспільства (сукупності соціальних спільнот). Таке розуміння школи (і не лише школи, а i будь-якого освітнього закладу) як специфічного соціального інституту, якому притаманні усі риси та характеристики класичної соціальної структури, зберігає актуальність і в наші дні. Взаємодія вчителя та учні - це взаємодія у певному соціальному середовищі, у особливому «соціальному полі», яке одначе має усі властивості традиційних соціальних систем.

Звідси випливає важливий висновок: найбільш важливою характеристикою освіти і освітнього процесу $є$ не стільки зміст навчання, скільки відповідність певним соціальним характеристикам та закладеним у ним структурам. Вказане здатне суттєво впливати і на якість освіти, вірніше на наше сприйняття якості, яка на практичному виступає відображенням нашого уявлення про певний ідеал (належна якість освіти виступає як наше сприйняття ідеальної освіти). «Сутність якості, з одного боку, легко, а з іншого - складно визначити однозначно. Відповідну категорію можна вважати універсальною, яку охоплює характеристики як зовнішніх по відношенню до людини явищ, так і суто внутрішніх.

Таким чином, якість освіти взагалі можна розглядати через реалізацію низки різних за значенням та структурою процесів, які мають об'єктивну або суб'єктивну природу. Якщо керуватися таким підходом, то якість освіти взагалі навряд чи може бути оцінена (хоча б тому, що у різних спільнот та осіб різні очікування щодо змісту та результатів освіти). На наш погляд, з урахуванням наукової та літературної спадщини В. В. Зеньковського, при дослідженні змістовності та характеристики якості освіти доцільно виходити із освітніх потреб особистості (людини), яка прагне вчитися (процес) і навчитися (результат). Тим більше, що В. В. Зеньковський, як педагог, психолог та мислитель, що осмислював фундаментальні освітні проблеми, запропонував низку теоретико-методологічних концепцій, які зможуть, у випадку належного опанування сучасниками, суттєво розширити інструментарій досліджень з питань якості освіти.

В цьому контексті цікавою видається інша теза, сформульована В. Зеньковським: «Сучасна школа у своїй побудові, в своїй роботі визначається двома задачами: повідомити учням деякі визначені знання та навички, відповідно до обраної спеціальності, і дати деяку «загальну» освіту, розвивати сили ума. Вища школа переважно вирішує перше завдання, середня - друге, але і в вищій школі в систему її включаться так звані «загальні предмети», і в середній школі чимало місця відводиться спеціальній підготовці учнів» [6]. Таким чином, В. В. Зеньковський сформулював ключову ознаку якісної освіти - по-перше, забезпечувати гармонійний розвиток особистості (зокрема, через вивчення «загальних» предметів), а по-друге, забезпечувати суспільне благо у вигляді фрахівців належної якості (зокрема, через отримання індивідами знань та навичок відповідно до обраної спеціальності). В цій тезі простежується призначення освітнього процесу як своєрідної «соціальної відповіді» на індивідуальні та суспільні запити. Згідно з В. Зеньковським, така «соціальна відповідь» має простежуватися на всіх рівнях освіти - і у середній освіті, і у вищій освіти.

Але слід звернути увагу на позицію В. В. Зеньковського щодо змісту професійної (спеціальної) освіти. Вчений зазначає, що «загальна» освіта має розвивати «сили ума», а вища (професійна) - забезпечувати отримання знань та навичок. Говорячи сучасною мовою, «загальна» освіта, яку здобувають як у середній школі, так і у системі вищої освіти, окрім простої «передачі знань» має навчити учня (студента) застосовувати свої інтелектуальні здібності, іншими словами - розвити навички до самопізнання та самонавчання. В той же час у професійній освіти студент (слухач) має отримати окрім знань ще і навички - іншими словами, навчитися застосовувати свої знання у конкретних практичних ситуаціях. Йдеться, таким чином, про комптентністний підхід. Лише така освіта, за В. В. Зеньковським, яка окрім простої «передачі знань» зосереджена на розвитку здатності до самопізнання та самонавчання, а також до практичних вмінь застосовувати знання у реалістичному (практичному) житті, може вважатися якісною.

В контексті предмета дослідження ми маємо пояснити природу компетентнісного підходу. Компетентнісний підхід - це спрямованість освітнього (навчально-виховного) процесу на досяг- 
нення результатів - ключових, загальнопредметних та предметних, які $є$ структурно підпорядкованими. Основні вимоги до компетенцій, що отримують здобувачі (студенти, учні, слухачі) в процесі навчання, повинні враховувати основі суспільні запити, і бути спрямовані на максимально гармонійне задоволення мети та завдань освіти. На наше глибоке переконання, цей підхід має застосовуватися на всіх рівнях освіти, від дошкільного та післядипломного.

В. Зеньковський, як відомо, основну увагу приділяв дослідженню процесів саме у середній школі. А тому питання забезпечення якості середньої освіти розроблені вченим більш повно. «Наша школа або виключно, або переважно дає розвиток ума, повідомляє низку знань та формальних навичок ума, - і це стоїть у найглибшому зв'язку із самими завданнями школи, - зазначає В. В. Зеньковський. - Які б дидактичні або методичні реформи ми не здійснювали у школі, але допоки її завдання залишаються тими, що до сьогодні визначають в основах її структуру, ці реформи усе ж йдуть поверхнево, не торкаючись змісту справи. Робота педагогічної думки має бути спрямована не на часткові реформи у школі (боротьба з перенавантаженням школи, багатопредметністю у ній тощо), а на самі її основи, тобто на її завдання» [6]. Відтак, вчений чудово розуміє, що якість освіти не можна забезпечити «простими перетвореннями», у тому числі і так званими «реформами», якщо не визначити з завданнями освіти як такої, якщо не визначитися із змістом і структурою самої школи та самого навчання.

Вказаний постулат як ніколи є актуальним і зараз, коли система освіти розвивається в умовах реформування усіх її рівнів.

На цю проблему звертає увагу і академік НАПН України В.Андрущенко, звернувши увагу на відсутність індивідуалізованої орієнтації освітніх інститутів, і називаючи наявний стан речей «антропологічною катастрофою» [2, с. 9]. В. Андрущенко в цьому контексті наголошує, що реформування освіти має враховувати в першу чергу сучасні потреби особистості, але з урахуванням кращої світової практики. Якщо провести паралелі з творчою спадщиною В. В. Зеньковського, то слід зазначити, що школа, якщо казати абстрактно, має взяти на себе відповідальність не лише за «знаннєву сфреру», але в першу чергу - за гармонійний розвиток особистості на основі задоволення її інтелектуальних, культурних і духовних запитів. Лише в такому разі освіта (принаймні, формальна), яку отримує особа, може вважатися якісною.

За В. Зеньковським, дати простий набір фактів (знань), хай навіть актуальних - важливе, але зовсім не єдине завдання будь-якої фрормальної освіти. Зауважимо, що сучасні інформаційні технології дозволяють протягом кількох секунд отримати будь-яку енциклопедичну або довідкову інформацію. Завдання освітніх інститутів, вважає В. В. Зеньковський, є значно ширшим, і полягає в першу чергу з відношенням індивіда до життя, до своєї участі у суспільних трансформаціях. «Люди закінчують школу з низкою знань та навичок, але з таким тупим ставленням і до справи своєї, и до життя, з такою відсутністю усілякої творчої сили та ініціативи, - з сумом писав В. Зеньковський. - Процес «навчання» потребує стільки сил, так виснажує творчі пориви, так нівелює особистість, підкоряє її шаблону, що, виходячи у життя, багато хто з нас перетворюється у безкольорових, в'ялих, тупих людей, що виконують якусь потрібну соціальну функцію, але безнадійно втратили творчу ініціативу та душевне ставлення до своєї діяльності». [4]. Отже, згідно позиції В. В. Зеньковського, яку він сформулював доволі чітко, результативність та якість освіти не може ототожнюватися з обсягом переданих та засвоєних знань. Певний набір знань, що може продемонструвати індивід, взагалі не є мірилом якості освіти. Важливо, або людина залишалася творчою, оптимістичною, або отримані знання дозволяли людині діяти самостійно, трансформуючи навколишнє середовище та соціальне середовище згідно з уявленнями про добро.

В. Зеньковський застерігає, що головне призначення освіти - це виховати творчу людину, що дуже тісно пов'язане із емоційною складовою. Творчу особистість можна виховати лише на основі вірної побудови її емоційного життя, зокрема на основі розкриття ії̈ емоційних сил. «Виходячи із школи, ми так багато знаємо, так багато вміємо, але часто наша індивідуальність проявляється лише у малому, в нашому побуті та інтимному житті, а у своїй діяльності ми не вміємо, і навіть не хочемо проявити творчість, - з сумом писав В. В. Зеньковський. - Головною і основною задачею нашої школи має стати охорона емоційного здоров'я та сприяння нормальному розкриттю та розквіту в нас емоційного життя. Усе інше має бути вторинним, має корелювати з тим, що потрібно для головного» [6].

Слова В. Зеньковського як ніколи звучать актуально зараз, коли проголошене реформування усієї освітянської сфрери, коли увага багатьох вчених та усього суспільства прикута до визначення клю- 
чових ознак сучасної школи: зміст освіти, її методи та принципи, варіативність навчання, масове діагностування особистісних запитів індивіда та надання адекватних відповідей на ці запити тощо.

В. Зеньковський звертає увагу, що школа (формальна освіта) привносить у освітній процес «порядок та систему», тим самим сприяючи кращому опануванню матеріалу. Але відповідь на питання «навіщо вчитися?» - це не питання наявності або відсутності певних технологій отримання «інформації про фракти», а скоріше - питання мотивації особистості до розвитку та пізнання навколишнього світу. Підтримка належної мотивації до навчання - це також завдання формальних освітніх інститутів. Не випадково В. В. Зеньковський нагадує: «Школа, таким чином, має i «обучати», тобто має прийняти дієву участь в тому розвитку ума, в тому засвоєнні різних знань, яке йде і поза школою. Діти, підлітки самі тягнуться до світла, до знання, зростаючий інтелект сам кличе їх до більш повного та глибокого розуміння, що діти та підлітки самі «тягнуться до світла», а завдання школи - спочатку пробудити, а потім вміло підтримувати інтерес до навчання» [6]. Лише вмотивоване навчання, за В. В. Зеньковським, може вважатися якісним.

Висновок. Творче осмислення наукової спадщини В. В. Зеньковського дає нам підставу зробити висновок, що мислитель розглядав проблему якості освіти в якості однієї із пріоритетних, яка має вирішуватися і на концептуально-фрілософрському рівні, і у повсякденній практиці. Освітній процес, з точки зору розуміння якості освіти за В. В. Зеньковським, розглядав не лише як набір прийомів «передачі знань», а з точки зору філософсько-антропологічної парадигми, за якою освіта має виховувати особистість, у тому числі (але не виключно) шляхом навчання. Ключовою ознакою якісної освіти В. В. Зеньковський вважав таку освіту, яка спонукає до творчості та самовираження. В той же час якісна освіта, на думку вченого, має прагнути до партнерської моделі взаємодії учасників освітнього (навчально-виховного) процесу. Вказані настанови, сфрормульовані В. Зеньковським, $є$ актуальними і навіть злободенними, і повинні бути використані в процесі рефрормування освітньої сфрери та усіх ії̈ ланок.

\section{Література}

1. Про освіту : Закон України від 23.05.1991 № 1060-XII [Електронний ресурс]. - Режим доступу : http://zakon0.rada.gov.ua/laws/show/1060-12 .

2. Про національну доктрину розвитку освіти [Електронний ресурс] Указ Президента від 17. 04.2002. № 347/2002. - Режим доступу http://zakon3.rada.gov.ua/laws/show/347/2002.

3. Андрущенко, В. Якість освіти як мета реформування вищої школи України / В. Андрущенко, В. Вікторов // Філософрсько-методологічні засади підвищення якості вищої освіти України : європейський вимір / авт. кол. : В. Андрущенко, М. Бойченко, Л. Горбунова, І. Надольний та ін. - К. : Педагогічна думка, 2012. -220 с.

4. Боднар, К. А. Розбудова української держави засобами освіти [Електронний ресурс] / К. А. Боднар // Вісник Харківського національного педагогічного університету імені Г. С. Сковороди. Філософрія. - 2013. - Вип. 41(1). - С. 232-240. - Режим доступу : http://nbuv.gov.ua/UJRN/VKhnpu filos 2013 41\%281\%29 22

5. Зеньковский, В. Предпосылки в строительстве новой школы / В. В. Зеньковский // Русская школа за рубежом. - № 2-3. - С. 216-230.

6. Зеньковский, В. В. Проблемы воспитания в свете христианской антропологии / В. В. Зеньковский // М. : СвятоВладимирское братство, 1993. - 271 с.

7. Зеньковский, В. Педагогика / В. Зеньковский; Фонд «Христианская жизнь». - Клин, 2002. - 224 с.

8. Зеньковский, В. В. Социальное воспитание, его задачи и пути. / В. В. Зеньковский. - М. : Моск. просвет, 1918. - 91 с.

9. Майбер, Б. Об онтологии качества образования в обществе знания / Б. Майер, Н. В. Наливайко // Философия образования. - 2008. - № 3. - С. 4-18.

10. Терепищий, С. О. Стандартизація вищої освіти як спосіб забезпечення ії якості (спроба фрілософрського аналізу) : моногр. / С. О. Терепищий. - К. : Вид-во НПУ ім. М. П. Драгоманова, 2010. - 197 с.

11. Філософрько-методологічні засади підвищення якості вищої освіти України : європейський вимір : кол. моногр. / авт. кол. : В. Андрущенко, М. Бойченко, Л. Горбунова, І. Надольний та ін. - К. : Педагогічна думка, 2012. -220 c.

\section{References}

1. Zakon Ukrainy pro osvitu vid 23.05.1991 № 1060-XII [Law of Ukraine About education]. (1991). zakono.rada.gov.ua. Retrieved from http://zakon0.rada.gov.ua/laws/show/1060-12 [in Ukrainian].

2. Andrushchenko, V. P. \& Viktorov, V. (2012). Yakist osvity yak meta reformuvannia vyshchoi shkoly Ukrainy. Filosofsko-metodolohichni zasady pidvyshchennia yakosti vyshchoi osvity Ukrainy: yevropeiskyi vymir [Philosophical and Methodological Principles for Improving the Quality of Higher Education in Ukraine: European Dimension]. Kyiv : Pedahohichna dumka. [in Ukrainian].

3. Bodnar, K. A. (2013). Rozbudova ukrainskoi derzhavy zasobamy osvity [Development of the Ukrainian state by means of education]. Visnyk Kharkivskoho natsionalnoho pedahohichnoho universytetu imeni H. S. Skovorody. Filosofiia - Visnyk Kharkivskoho natsionalnoho pedahohichnoho universytetu imeni H. S. Skovorody. Filosofiia, 41(1), $232-240$. nbuv.gov.ua. Retrieved from http://nbuv.gov.ua/UJRN/VKhnpu_filos_2013_41\%281\%29_22 [in Ukrainian]. 
4. Zenkovskiy, V. (1923). Predposyilki v stroitelstve novoy shkolyi [The background in the construction of new school]. Russian school abroad - Russkaya shkola za rubezhom, 2-3, 216-230 [in Russian].

5. Zenkovskiy, V. V. (1993). Problemyi vospitaniya $v$ svete hristianskoy antropologii [Problems of education in christian anthropology]. Moscow : St. Vladymyr brotherhood [in Russian].

6. Zenkovskiy, V. V. (2002) Pedahohyka [Pedagogy]. Klyn [in Russian].

7. Zenkovskiy, V. V. (1918). Sotsialnoe vospitanie, ego zadachi i puti [Social education, its tasks and ways]. Moscow lumen [in Russian].

8. Maiber, B. \& Nalyvaiko, N. V. (2008). Ob ontolohii kachestva obrazovanyia v obshchestve znanyia [Ob ontologii kachestva obrazovaniya v obshchestve znaniya]. Fylosofyia obrazovanyia - Filosofiya obrazovaniya, 3, 4-18 [in Russian].

9. Terepyshchyi, S. O. (2010). Standartyzatsiia vyshchoi osvity yak sposib zabezpechennia yii yakosti (sproba filosofskoho analizu) [Standartyzatsiia vyshchoi osvity yak sposib zabezpechennia yii yakosti (sproba filosofskoho

analizu)]. Kyiv : Vyd-vo NPU im. M. P. Drahomanova [in Ukrainian].

10. Andrushchenko, V., Boichenko, M., L. Horbunova, L. \& Nadolnyi, I. (2012). Filosofsko-metodolohichni zasady pidvyshchennia yakosti vyshchoi osvity Ukrainy : yevropeiskyi vymir [Philosophical and Methodological Principles for Improving the Quality of Higher Education in Ukraine: European Dimension]. Kyiv : Pedahohichna dumka [in Ukrainian].

\section{Бібліографічний опис для цитування :}

Надійшла 14.11.2018

Захаріна, М. І. Філософрько-педагогічне осмислення В. Зеньковським якості освіти: паралелі із сучасністю / М. І. Захаріна, А. Д. Мекшун // Проблеми соціальної роботи: фрілософія, психологія, соціологія. - 2018. - № 2 (12). - C. $36-43$. 